\title{
DPPA3 wt Allele
}

National Cancer Institute

\section{Source}

National Cancer Institute. DPPA3 wt Allele. NCI Thesaurus. Code C95053.

Human DPPA3 wild-type allele is located in the vicinity of 12 p13.31 and is approximately 6 $\mathrm{kb}$ in length. This allele, which encodes developmental pluripotency-associated protein 3 , is involved in the maintenance of stem cell pluripotency. 